
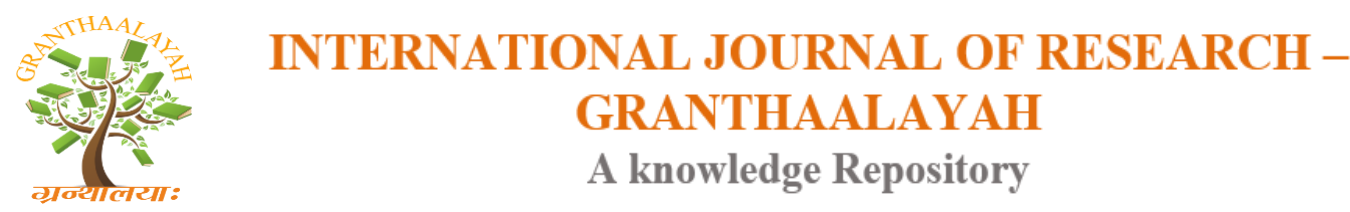

Science

\title{
BIRD DIVERSITY IN SHENDI AREA, SUDAN
}

\author{
Yassir Sulieman *1, Theerakamol Pengsakul ${ }^{2}$, Azzam Afifi ${ }^{3}$, Mohamed A. Zakaria ${ }^{4}$ \\ ${ }^{* 1}$ Department of Zoology, Faculty of Science and Technology, University of Shendi, SUDAN \\ ${ }^{2}$ Faculty of Medical Technology, Prince of Songkla University, Hat Yai, Songkhla 90110, \\ THAILAND \\ ${ }^{3}$ Department of Zoology, Faculty of Science and Technology, Omdurman Islamic University, \\ SUDAN \\ ${ }^{4}$ Department of Biology, Faculty of Education, University of Nyala, SUDAN \\ DOI: https://doi.org/10.29121/granthaalayah.v4.i6.2016.2638
}

\section{ABSTRACT}

The present study was conducted from July to December 2015 and found that the Shendi area, River Nile State, Sudan, Africa, hosts considerable bird diversity with 35 species being observed belonging to 22 families; of which Columbidae, Meropidae and Nectariniidae were the most frequently observed species.

Keywords:

Bird; Diversity; Shendi; Sudan.

Cite This Article: Yassir Sulieman, Theerakamol Pengsakul, Azzam Afifi, and Mohamed A. Zakaria, "BIRD DIVERSITY IN SHENDI AREA, SUDAN" International Journal of Research Granthaalayah, Vol. 4, No. 6 (2016): 55-63.

\section{INTRODUCTION}

Birds are among the best known parts of the Earth's biodiversity (Pomeroy, 1992; Bibby et al., 1998). They have long served humans for game, food, and feathers, as well as in their predatory capacity as destroyers of insects and rodents (Collins, 1981). In addition, they are considered as good indicators of the degree of human disturbance in the various ecosystems worldwide. Their population abundance has been found to change considerably due to anthropogenic activities (Askins et al., 1990; Bock et al., 2001).

In Sudan, studies of the avifauna and its seasonal variation have been carried out by many ornithologists in various locations, including Dinder National Park, Sunut Forest and Tuti Island (Hamad, 1998). The avifauna of Sudan numbers more than 630 species, of which the majority is resident and some are regular seasonal migrants (Dowsett et al., 2016). 
The objective of the present study was to provide a baseline of information on the biodiversity of birds within the area of Shendi, a city located in the northern part of Sudan.

\section{MATERIALS AND METHODS}

\subsection{STUDY AREA}

The present study was conducted in Shendi, a city situated on the east bank of the River Nile, in northern Sudan, its geo-coordinates being $16^{\circ} 40^{\prime} 52^{\prime \prime} \mathrm{N}$ and $33^{\circ} 25^{\prime} 7^{\prime \prime} \mathrm{E}$. This area has a semi arid climate with a short rainy period between August and September with a mean precipitation of $29.3 \mathrm{~mm}$, and an annual temperature ranging from $28-41^{\circ} \mathrm{C}$. The flora of the Shendi area is poor and sparse in the desert zones, and is virtually absent except along the banks of the River Nile, where there are agricultural lands used for fruits, vegetables and other crops. The inhabitants of the area have diverse occupations ranging from farming and fishing to trading activities.

\subsection{BIRD OBSERVATION}

The Birds were observed and recorded at different locations from July to December 2015 within Shendi city and its adjacent areas, including the River Nile bank opposite the study area. The bird observation and sighting was conducted weekly, in the morning and evening for two to three hours, using field binoculars (Comet, 8x42). The taxonomy and nomenclature of the birds observed were performed following Stevenson and Fanshawe, 2002 and their status information was tabulated according to Dowsett et al., 2016 and the IUCN Red List of Threatened Species, (2015). The numbers of individuals observed were counted when numbers were limited or estimated when numbers were huge. Birds were photographed using a digital camera (Samsung, 13 Mega pixels) whenever that was possible.

\section{RESULTS}

Thirty-five bird species with various abundances were observed in the present study belonging to 22 families (Table 1). The highest number of birds observed was in September (Table 1). While the families observed with the maximum numbers of different species were Columbidae, Meropidae and Nectariniidae (Tables 1 and 2).

The monthly number of birds observed during the study period was as shown in table (1) and their species status is shown in table (2). Photographs of some of the birds observed appear as figures 1-18. Out of the 35 species observed, $22(62.9 \%)$ are residents in the country as confirmed by breeding records and six (17.1\%) are migrants which are known to breed in the area, including those in passage across the country as also confirmed by breeding records. Two $(5.7 \%)$ species breed in the Palearctic and winter in the area, one $(2.9 \%)$ is a species with both a resident breeding population and a wintering population, one $(2.9 \%)$ has both a migrant breeding population and a wintering population, one $(2.9 \%)$ breeds in the Palearctic but is not recorded previously as wintering in the area, and one (2.9\%) species is resident although there is no record of it breeding in the area (Table 2). 
Table 1: List of bird species and numbers observed from July to December 2015, Shendi area, Sudan.

\begin{tabular}{|c|c|c|c|c|c|c|c|c|c|c|}
\hline \multirow{2}{*}{ No. } & \multirow{2}{*}{ Family } & \multirow{2}{*}{ Species scientific name } & \multirow[t]{2}{*}{ Species English name } & \multicolumn{6}{|c|}{ Numbers observed in 2015} & \multirow{2}{*}{$\begin{array}{l}\text { Total } \\
\text { No. }\end{array}$} \\
\hline & & & & Jul. & Aug & Sep. & Oct. & Nov & Dec. & \\
\hline \multirow{3}{*}{1} & \multirow{3}{*}{ Columbidae } & Streptopelia roseogrisea & African Collared-dove & 06 & 18 & 22 & 04 & 45 & 19 & 114 \\
\hline & & Streptopelia senegalensis & Laughing Dove & 43 & 36 & 20 & 40 & 37 & 40 & 216 \\
\hline & & Oena capensis & Namaqua Dove & 10 & 05 & 10 & 06 & 00 & 02 & 33 \\
\hline \multirow{3}{*}{2} & \multirow{3}{*}{ Meropidae } & Merops orientalis & Little Green Bee-eater & 09 & 15 & 11 & 16 & 02 & 07 & 60 \\
\hline & & Merops albicollis & White-throated Bee-eater & 00 & 01 & 05 & 00 & 02 & 02 & 10 \\
\hline & & Merops pusillus & Little Bee-eater & 00 & 00 & 07 & 00 & 00 & 00 & 07 \\
\hline \multirow{3}{*}{3} & \multirow{3}{*}{ Nectariniidae } & Cinnyris pulchellus & Beautiful Sunbird & 00 & 03 & 00 & 00 & 00 & 00 & 03 \\
\hline & & Hedydipna platura & Pygmy Sunbird & 00 & 02 & 00 & 00 & 00 & 00 & 02 \\
\hline & & Hedydipna metallica & Nile Valley Sunbird & 00 & 00 & 02 & 00 & 00 & 00 & 02 \\
\hline \multirow[b]{2}{*}{4} & \multirow{2}{*}{ Ploceidae } & Ploceus cucullatus & Village Weaver & 01 & 01 & 08 & 00 & 00 & 00 & 10 \\
\hline & & Euplectes franciscanus & Northern Red Bishop & 00 & 00 & 05 & 00 & 00 & 00 & 05 \\
\hline \multirow{2}{*}{5} & \multirow{2}{*}{ Ciconiidae } & Ciconia abdimii & Abdim's Stork & 21 & 06 & 08 & 00 & 00 & 00 & 35 \\
\hline & & Anastomus lamelligerus & African Openbill & 00 & 00 & 00 & 00 & 02 & 00 & 02 \\
\hline \multirow[b]{2}{*}{6} & \multirow[b]{2}{*}{ Muscicapidae } & Cercotrichas podobe & Black Scrub-robin & 00 & 00 & 06 & 00 & 00 & 00 & 06 \\
\hline & & Erythropygia galactotes & $\begin{array}{l}\text { Rufous-tailed Scrub- } \\
\text { robin }\end{array}$ & 00 & 00 & 03 & 00 & 00 & 00 & 03 \\
\hline \multirow[t]{2}{*}{7} & \multirow[t]{2}{*}{ Alaudidae } & Eremopterix nigriceps & $\begin{array}{c}\text { Black-crowned Sparrow } \\
\text {-lark }\end{array}$ & 00 & 00 & 13 & 00 & 00 & 00 & 13 \\
\hline & & Melanocorypha bimaculata & Bimaculated Lark & 00 & 00 & 01 & 02 & 00 & 00 & 03 \\
\hline \multirow{2}{*}{8} & \multirow{2}{*}{ Charadriidae } & Vanellus spinosus & Spur-winged lapwing & 13 & 12 & 02 & 00 & 00 & 04 & 31 \\
\hline & & Charadrius dubius & Little Ringed Plover & 00 & 00 & 00 & 00 & 03 & 00 & 03 \\
\hline \multirow[b]{2}{*}{9} & \multirow{2}{*}{ Viduidae } & Vidua chalybeate & Village Indigobird & 00 & 00 & 01 & 00 & 02 & 00 & 03 \\
\hline & & Vidua macroura & Pin-tailed Whydah & 00 & 00 & 04 & 00 & 00 & 00 & 04 \\
\hline \multirow{2}{*}{10} & Estrildidae & Lagonosticta senegala & Red-billed Firefinch & 02 & 00 & 01 & 00 & 06 & 02 & 11 \\
\hline & Estrildiaae & Lonchura cantans & African Silverbill & 05 & 02 & 00 & 00 & 00 & 00 & 07 \\
\hline 11 & Upupidae & Upupa epops & Common Hoopoe & 01 & 00 & 03 & 00 & 00 & 00 & 04 \\
\hline 12 & Accipitridae & Milvus migrans & Black Kite & 04 & 09 & 03 & 01 & 02 & 32 & 51 \\
\hline 13 & Passeridae & Passer domesticus & House Sparrow & 240 & 142 & 220 & 123 & 108 & 267 & 1100 \\
\hline 14 & Apodidae & Cypsiurus parvus & African Palm-swift & 00 & 23 & 48 & 03 & 28 & 13 & 115 \\
\hline 15 & Ardeidae & Bubulcus ibis & Cattle Egret & 21 & 02 & 06 & 01 & 0 & 07 & 37 \\
\hline 16 & Threskiornithidae & Threskiornis aethiopicus & African Sacred Ibises & 00 & 00 & 130 & 30 & 00 & 00 & 160 \\
\hline 17 & Coliidae & Urocolius macrourus & Blue-naped Mousebird & 30 & 23 & 29 & 02 & 05 & 00 & 89 \\
\hline 18 & Falconidae & Falco naumanni & Lesser Kestrel & 01 & 00 & 00 & 00 & 01 & 00 & 02 \\
\hline 19 & Motacillidae & Motacilla aguimp & African Pied Wagtail & 00 & 00 & 00 & 00 & 20 & 00 & 20 \\
\hline 20 & Pycnonotidae & Pycnonotus barbatus & Common Bulbul & 14 & 15 & 18 & 03 & 04 & 02 & 56 \\
\hline 21 & Cerylidae & Ceryle rudis & Pied Kingfisher & 00 & 00 & 00 & 00 & 00 & 01 & 01 \\
\hline 22 & Pluvianidae & Pluvianus aegyptius & Egyptian Plover & 00 & 00 & 00 & 00 & 02 & 03 & 05 \\
\hline & & Total number observed & & 421 & 315 & 586 & 231 & 269 & 401 & 2223 \\
\hline
\end{tabular}


Table 2: Bird species and their general status observed in Shendi area, Sudan, from July to December 2015.

\begin{tabular}{|c|c|c|c|c|c|c|c|}
\hline No. & Family & $\begin{array}{c}\text { Species } \\
\text { total } \\
\text { number }\end{array}$ & Species scientific name & Status & $\begin{array}{c}\text { IUCN } \\
\text { red list }\end{array}$ & $\begin{array}{c}\text { Population } \\
\text { trend }\end{array}$ & $\begin{array}{c}\text { Total number } \\
\text { observed }\end{array}$ \\
\hline \multirow{3}{*}{1} & \multirow{3}{*}{ Columbidae } & \multirow[t]{3}{*}{ 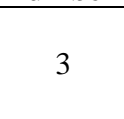 } & Streptopelia roseogrisea & RB & LC & Stable & 114 \\
\hline & & & Streptopelia senegalensis & $\mathrm{RB}$ & LC & Stable & 216 \\
\hline & & & Oena capensis & MB & LC & Increasing & 33 \\
\hline \multirow{3}{*}{2} & \multirow{3}{*}{ Meropidae } & \multirow{3}{*}{3} & Merops orientalis & $\mathrm{RB}$ & LC & Increasing & 60 \\
\hline & & & Merops albicollis & MB & LC & Stable & 10 \\
\hline & & & Merops pusillus & $\mathrm{RB}$ & LC & Decreasing & 7 \\
\hline \multirow{3}{*}{3} & \multirow{3}{*}{ Nectariniidae } & \multirow{3}{*}{3} & Cinnyris pulchellus & $\mathrm{RB}$ & $\S$ & $\S$ & 3 \\
\hline & & & Hedydipna platura & RB & $\S$ & $\S$ & 2 \\
\hline & & & Hedydipna metallica & $\mathrm{RB}$ & $\S$ & $\S$ & 2 \\
\hline \multirow{2}{*}{4} & \multirow{2}{*}{ Ploceidae } & \multirow{2}{*}{2} & Ploceus cucullatus & $\mathrm{RB}$ & LC & Stable & 10 \\
\hline & & & Euplectes franciscanus & $\mathrm{RB}$ & $\mathrm{LC}$ & Stable & 5 \\
\hline \multirow{2}{*}{5} & \multirow{2}{*}{ Ciconiidae } & \multirow{2}{*}{2} & Ciconia abdimii & MB & LC & Decreasing & 35 \\
\hline & & & Anastomus lamelligerus & MB & LC & Decreasing & 2 \\
\hline \multirow[b]{2}{*}{6} & \multirow{2}{*}{ Muscicapidae } & \multirow{2}{*}{2} & Cercotrichas podobe & $\mathrm{RB}$ & $\mathrm{LC}$ & Stable & 6 \\
\hline & & & Erythropygia galactotes & RB & LC & Stable & 3 \\
\hline \multirow{2}{*}{7} & \multirow{2}{*}{ Alaudidae } & \multirow{2}{*}{2} & Eremopterix nigriceps & $\mathrm{RB}$ & LC & Increasing & 13 \\
\hline & & & Melanocorypha bimaculata & $\mathrm{PW}$ & LC & Stable & 3 \\
\hline \multirow{2}{*}{8} & \multirow{2}{*}{ Charadriidae } & \multirow{2}{*}{2} & Vanellus spinosus & RB & LC & Increasing & 31 \\
\hline & & & Charadrius dubius & $\mathrm{PW}$ & LC & Stable & 3 \\
\hline \multirow{2}{*}{9} & \multirow{2}{*}{ Viduidae } & \multirow{2}{*}{2} & Vidua chalybeate & $\mathrm{RB}$ & $\S$ & $\S$ & 3 \\
\hline & & & Vidua macroura & RB & LC & Stable & 4 \\
\hline & & & Lagonosticta senegala & $\mathrm{RB}$ & LC & Stable & 11 \\
\hline 10 & Estrildidae & 2 & Lonchura cantans & $\mathrm{RB}$ & LC & Stable & 7 \\
\hline 11 & Upupidae & 1 & Upupa epops & $\mathrm{RB} / \mathrm{PW}$ & LC & Decreasing & 4 \\
\hline 12 & Accipitridae & 1 & Milvus migrans & $\mathrm{MB} / \mathrm{PW}$ & LC & Unknown & 51 \\
\hline 13 & Passeridae & 1 & Passer domesticus & $\mathrm{RB}$ & LC & Decreasing & 1100 \\
\hline 14 & Apodidae & 1 & Cypsiurus parvus & $\mathrm{RB}$ & LC & Increasing & 115 \\
\hline 15 & Ardeidae & 1 & Bubulcus ibis & $\mathrm{MB} / \mathrm{P}$ & LC & Increasing & 37 \\
\hline 16 & Threskiornithidae & 1 & Threskiornis aethiopicus & $\mathrm{MB}$ & LC & Decreasing & 160 \\
\hline 17 & Coliidae & 1 & Urocolius macrourus & RB & LC & Decreasing & 89 \\
\hline 18 & Falconidae & 1 & Falco naumanni & $\mathrm{P}$ & LC & Stable & 2 \\
\hline 19 & Motacillidae & 1 & Motacilla aguimp & $\mathrm{R}$ & LC & Stable & 20 \\
\hline 20 & Pycnonotidae & 1 & Pycnonotus barbatus & RB & LC & Increasing & 56 \\
\hline 21 & Cerylidae & 1 & Ceryle rudis & $\mathrm{RB}$ & LC & Unknown & 1 \\
\hline 22 & Pluvianidae & 1 & Pluvianus aegyptius & $\mathrm{MB}$ & LC & Decreasing & 5 \\
\hline & & & Total number observed & & & & 2223 \\
\hline
\end{tabular}

Key to status information:

$\mathrm{B}$ - Breeding record confirmed; $\mathrm{M}$ - Migrant including on passage through Sudan;

$\mathrm{P}$ - Breeds in Palearctic; R - Resident; W - Winters in Sudan (non-breeding season);

$\mathrm{RB}$ - Resident in Sudan as confirmed by breeding record; PW - Breeds in the Palearctic and winters in Sudan; AM

- Intra African Migrant;

$\mathrm{RB} / \mathrm{PW}$ - There is both a resident breeding population and a wintering population;

LC - Least Concern; $\S-$ Not yet assessed for the IUCN Red List. 


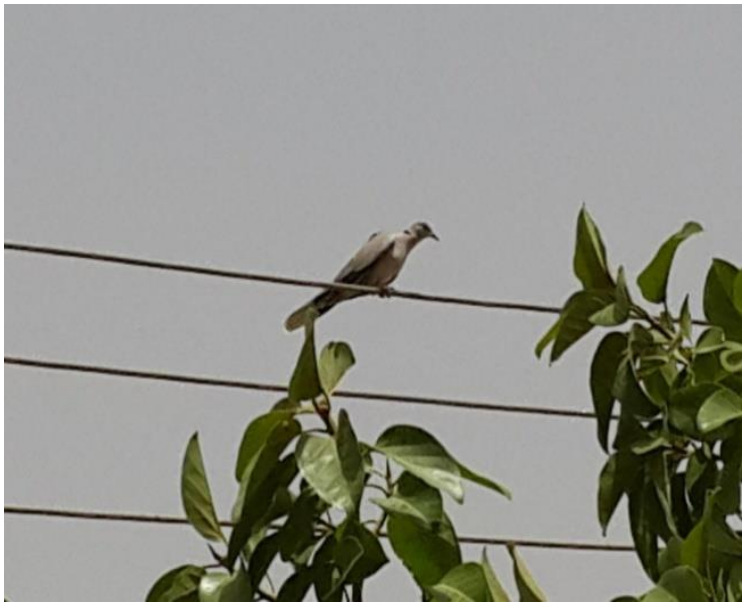

Figure 1: African Collared Dove, Streptopelia roseogrisea

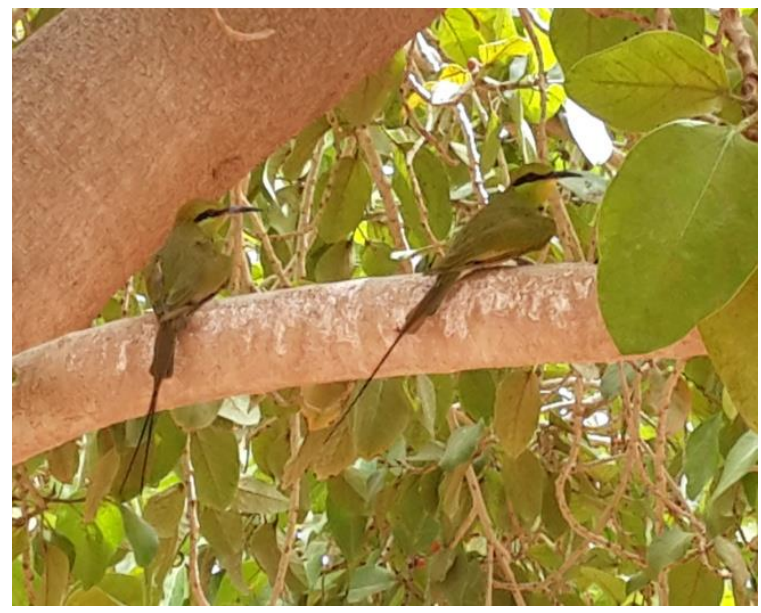

Figure 3: Little Green Bee-eater, Merops orientalis

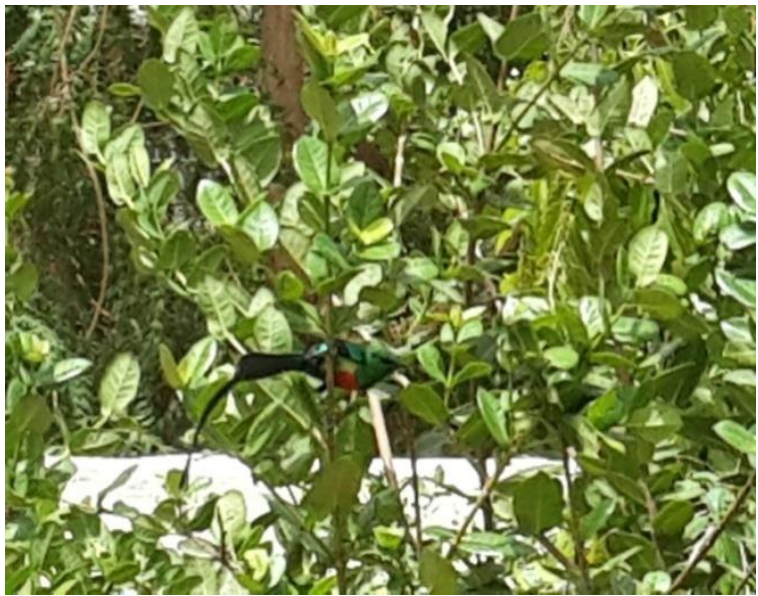

Figure 5: Beautiful Sunbird, Cinnyris pulchellus

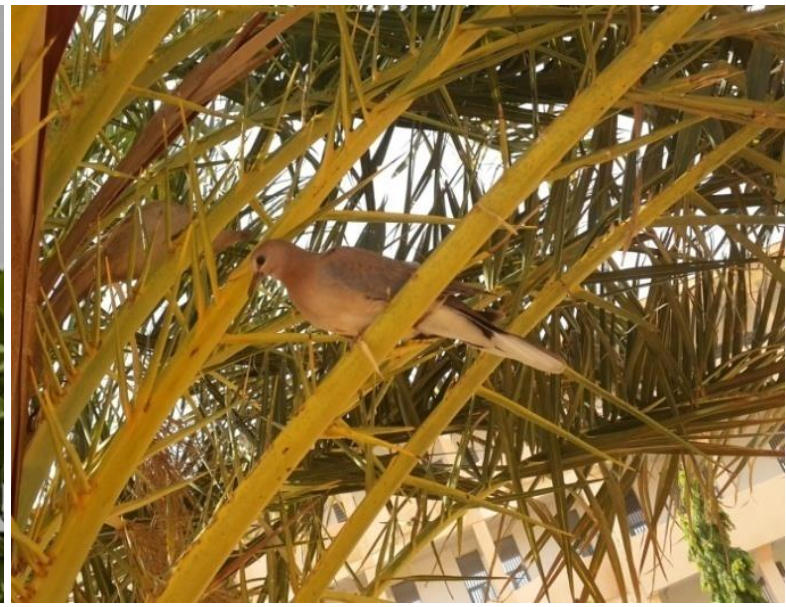

Figure 2: Laughing Dove, Streptopelia senegalensis

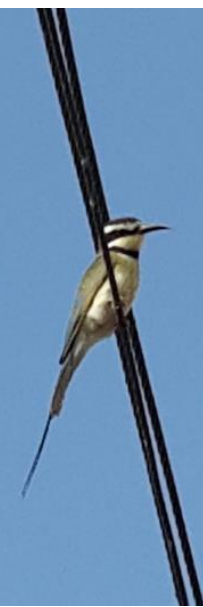

Figure 4: White-throated Bee-eater, Merops albicollis

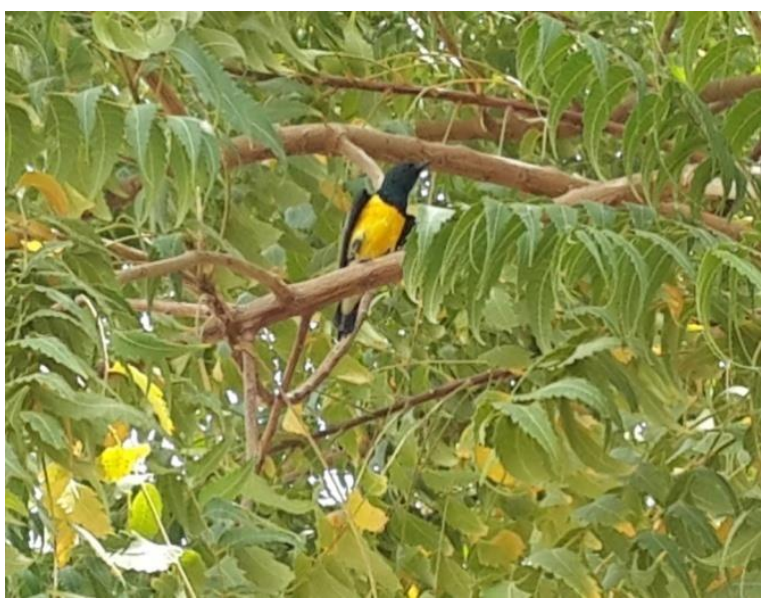

Figure 6: Nile Valley Sunbird, Hedydipna metallica 


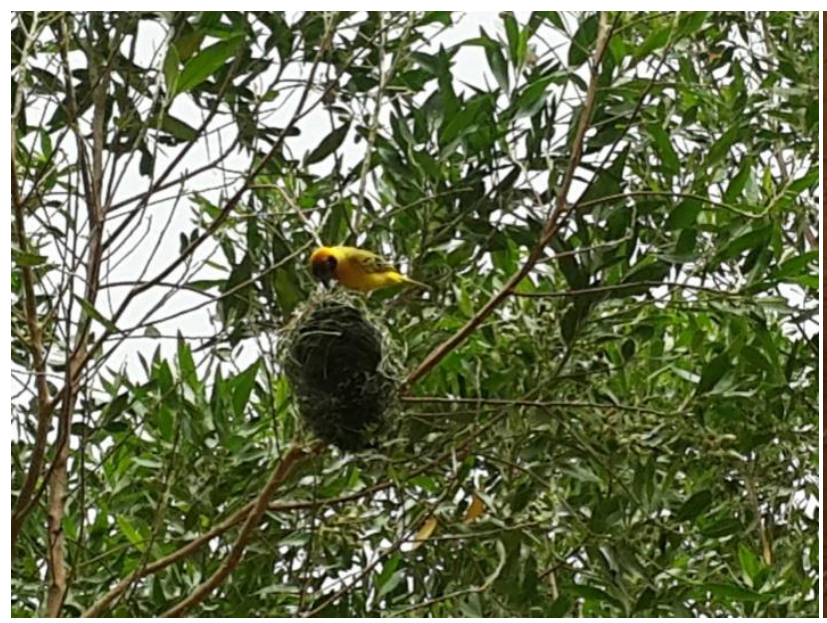

Figure 7: Village Weaver, Ploceus cucullatus

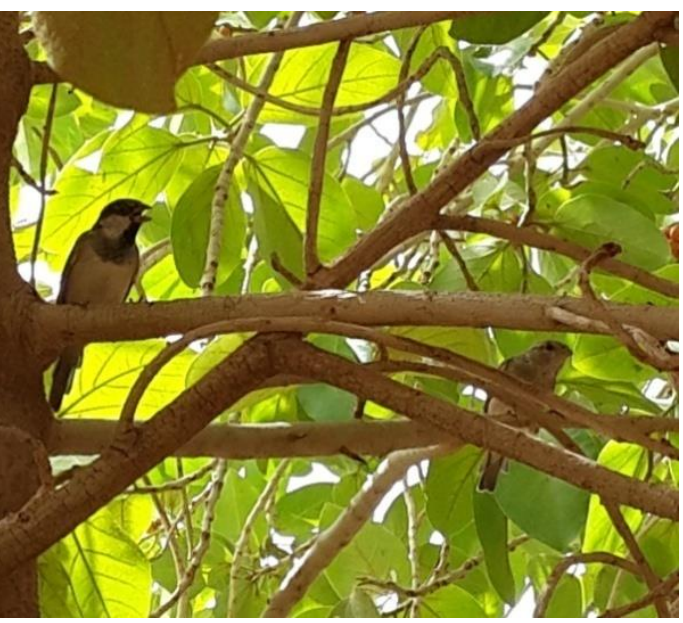

Figure 8: House Sparrow, Passer domesticus

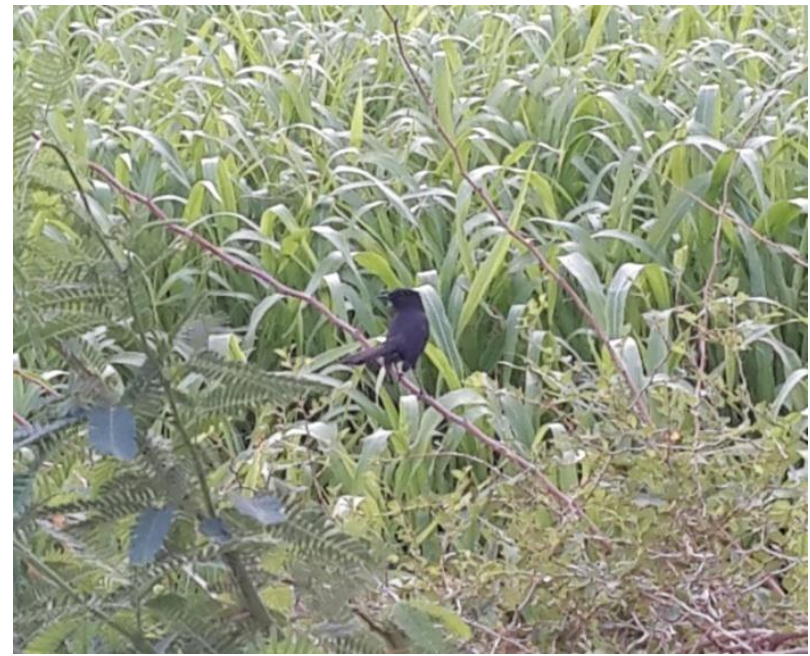

Figure 9: Black Scrub-robin, Cercotrichas podobe

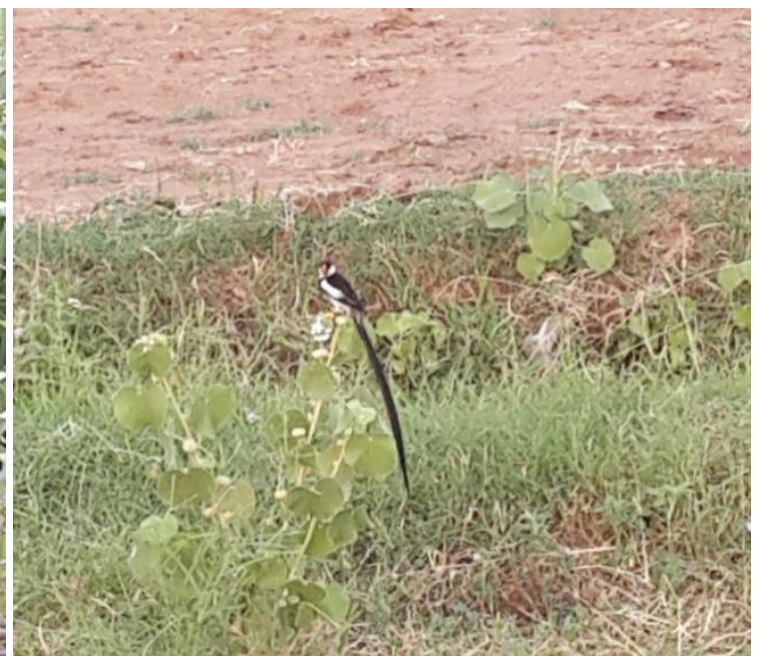

Figure 10: Pin-tailed Whydah, Vidua macroura

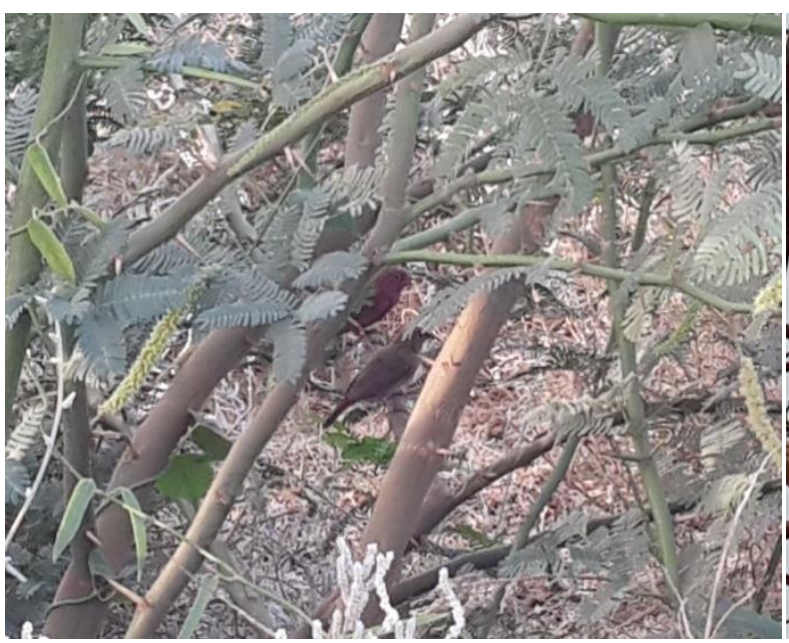

Figure 11: Red-billed Firefinch, Lagonosticta senegala

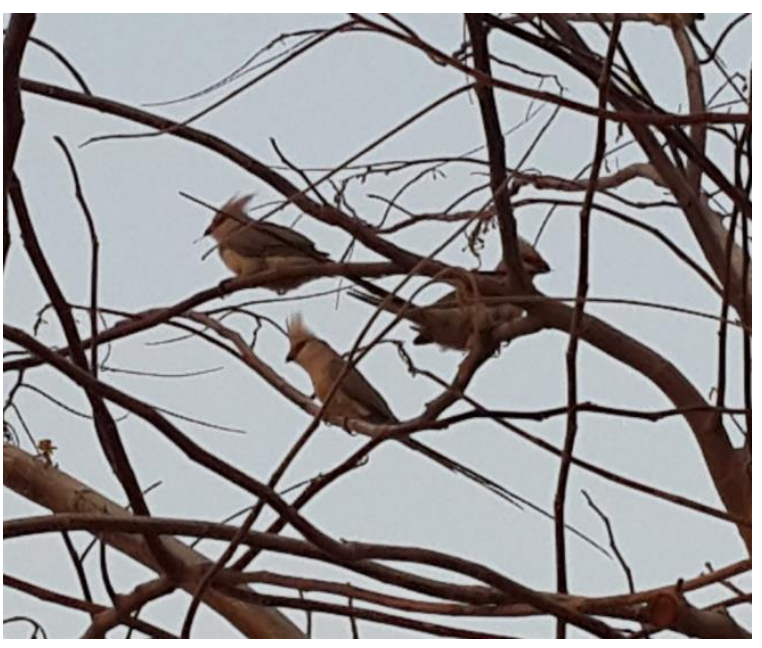

Figure 12: Blue-naped Mousebird, Urocolius macrourus 


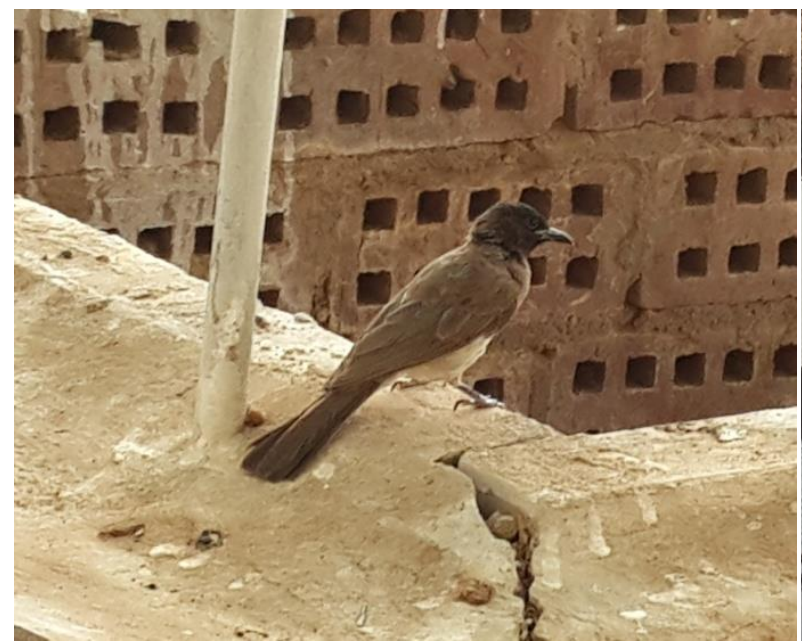

Figure 13: Common Bulbul, Pycnonotus barbatus

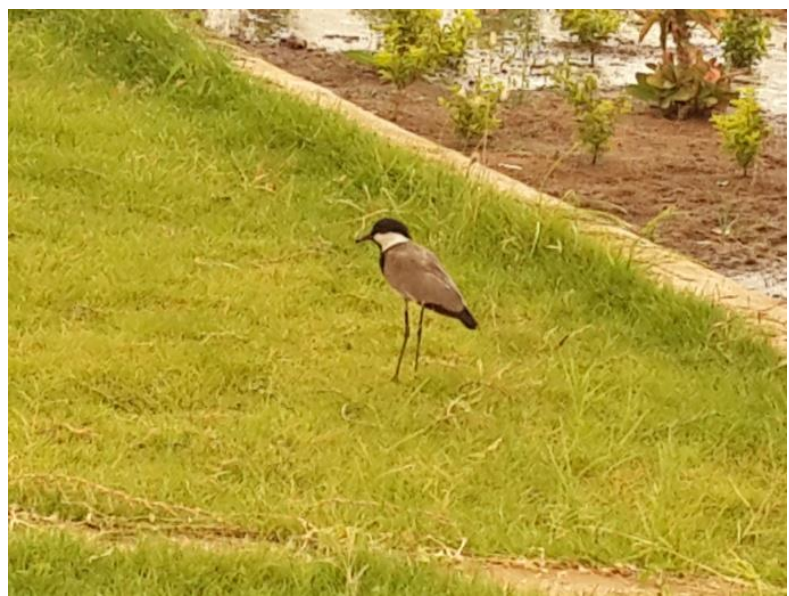

Figure 15: Spur-winged lapwing, Vanellus spinosus

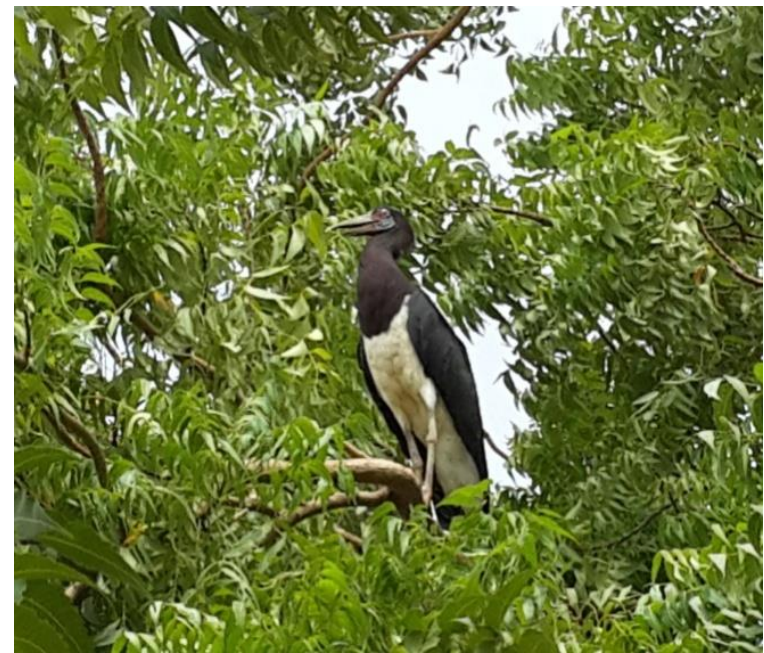

Figure 17: Abdim's Stork, Ciconia abdimii

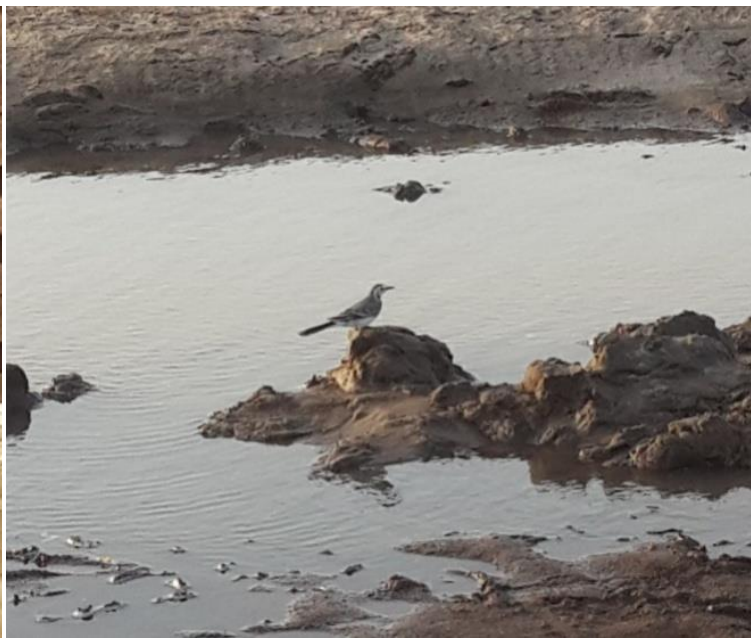

Figure 14: African Pied Wagtail, Motacilla aguimp

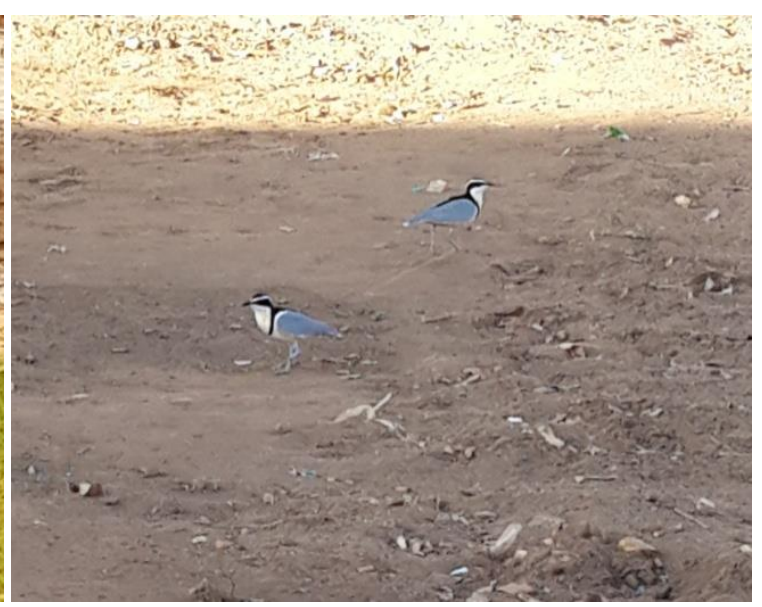

Figure 16: Egyptian Plover, Pluvianus aegyptius

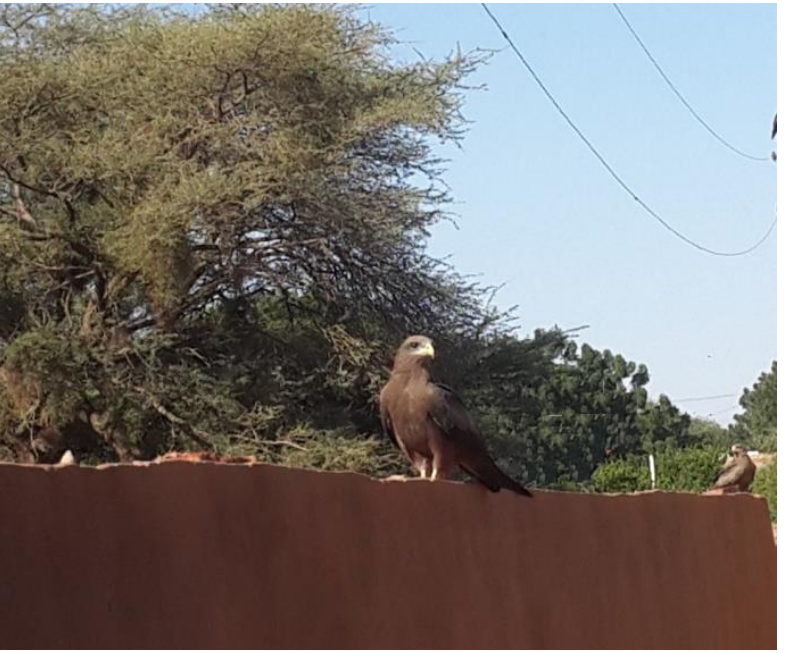

Figure 18: Black Kite, Milvus migrans 


\section{DISCUSSION}

In the present study, 35 species of bird were observed. This result reflects the richness of the avifauna of the Shendi area, especially during the migration season in the autumn. This richness is probably due to the use of the area for gardens and orchards and hence the availability of food, as well as the flora of the River Nile banks, which is diverse and contains a wide range of different trees providing a wide range of microhabitats for different species of birds. It is well known that vegetation cover has a strong influence on the avifauna (Scott-Mills et al., 1989). The River Nile is an important flyway for migratory waterbirds moving between Africa, Europe and the Middle East. It provides a considerable amount of suitable habitats for feeding, nesting or resting sites for birds. Variations in the structure of the bird community noted during the study period could be attributed to bird migration, with some migrating birds arriving in the area for breeding or using it as a stopover site for food supply. Previous studies in Sudan have recorded more than 160 species of birds from the Dinder National Park, 24 species from Sunut Forest, 30 species from Tuti Island and 23 species from the El Ga'ab depression (Salah and Idris, 2013; Mahmoud et al., 2015).

The relatively high diversity of birds observed in the present study suggests that the habitat of the area is suitable for birds. However, increasing anthropogenic activities are a matter of great concern when considering the future existence of these species. Sudan has lost a number of wildlife species in the last two decades and this is mostly due to habitat destruction; several varieties of grasses and herbs have disappeared due to overgrazing, and repeated droughts and fires. In the Shendi area, the main threat that affects birds is the destruction of their habitat by tree cutting for agricultural use. This practice reflects low awareness and sensitivity to environmental issues among both the public and policy makers. Moreover, development and construction projects in the Shendi area may have a negative impact on bird habitats, for example, the construction of El Mack Nimer Bridge and the cutting of old large trees such as Acacia spp. and Azadirachta sp. or Neem trees near the main market to facilitate new buildings constructed for the purpose of investment has resulted in the destruction of the nests and resting sites of many bird species, including the Cattle Egret and Abdims Stork. Previous studies have concluded that urbanization, industrialization, the draining of wetlands and the widespread use of pesticides pose a threat to birds (Donald and Gregory, 2002; Liven-Schulman et al., 2004). Moreover, many wildlife species are endangered because of illegal hunting or over-hunting (Yom-Tov, 2003).

In conclusion, this study will provide a baseline of information for future studies concerning the birds of the Shendi area.

\section{ACKNOWLEDGEMENTS}

The authors would like to thank Djbril Tia, University of Shendi for his assistance during the field work. 


\section{REFERENCES}

[1] Askins, R.A., Lynch, J.F., Greenburg, R. 1990. Population declines in migratory birds in eastern North America. Current Ornithology, 7: 1-57.

[2] Bibby, C., Jones, M., Marsden, S. 1998. Expedition field techniques: Bird surveys. Expedition Advisory Center, Royal Geographical Society (with the Institute of British Geographers), London, $134 \mathrm{pp}$.

[3] Bock, C.E., Bock, J.H., Bennett, B.C. 2001. Songbird abundance in grasslands at a suburban interface on the Colorado high plains. Studies in Avian Biology, 19: 131-136.

[4] Collins, H.H. 1981. Harper and Row's complete field guide to North American wildlife. Eastern edition, Harper and Row's, Publishers, 714 pp.

[5] Donald, P.F., Gregory, R.D. 2002. Silent fields: The decline of farmland birds in Europe. Biologist, 49(3): 101-106.

[6] Dowsett, R.J., Atkinson, P.W., Caddick, J.A. 2016. Checklist of the birds of Sudan. Downloaded from www.africanbirdclub.org 13 February 2016.

[7] Hamad, D.M. 1998. Bird fauna in Dinder National Park. Sudan Notes and Records (SNR), 2:187-203.

[8] IUCN Red List of Threatened Species. Version 2015-4. 〈www.iucnredlist.org>. Downloaded on 15 February 2016.

[9] Liven-Schulman, I., Leshem, Y., Alon, D., Yom-Tov, Y. 2004. Causes of population declines of the lesser kestrel Falco naumanni in Israel. Ibis, 146(1): 145-152.

[10] Mahmoud, Z.N., Tahir,, Y.F., Hamdeen, H.M. 2015. Birds of El Ga'ab depression, Sudan. European Academic Research, 3(4): 4408-4415.

[11] Pomeroy, D. 1992. Counting birds. AWF technical handbook series 6, African Wildlife Foundation (AWF), Nairobi, Kenya, 48 pp.

[12] Salah, O., Idris, E., 2013. A note on the bird diversity at two sites in Khartoum, Sudan. Egyptian Academic Journal of Biological Sciences, 5(1): 1-10.

[13] Scott-Mills, G., Dunning J.B., Bates, J.M. 1989. Effects of urbanization on breeding bird community structure in southwestern desert habitats. Condor, 91: 416-428.

[14] Stevenson, T., Fanshawe, J. 2002. Birds of East Africa. Christopher Helm, London.

[15] Yom-Tov, Y. 2003. Poaching of Israeli wildlife by guest workers. Biological Conservation, 110: 11-20. 